\title{
Methods for qualitative and quantitative analysis of pain and quality of life validated in Brazil: systematic review
}

\author{
Métodos de análise qualitativa e quantitativa da dor \\ e qualidade de vida validadas no Brasil: \\ revisão sistemática
}

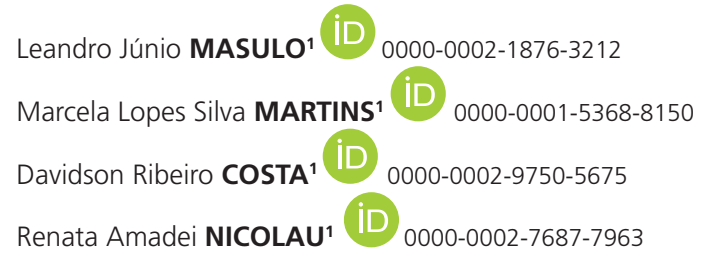

\section{ABSTRACT}

Objective: The need to quantify pain and quality of life (QoL) is essential for professionals considering their therapeutic approach. The goal of this review is to identify the methods to perform qualitative and quantitative analysis of pain and QoL validated in Brazil. Methods: Review by the LILACS, SciELO, MedLine and Google Scholar databases with the descriptors: methods, qualitative analysis, quantitative analysis, pain and quality of life. Inclusion criteria: articles published in Portuguese and in English in the period from 1996 to 2015. Exclusion criteria: incomplete texts, articles that did not address the subject of study and duplicate articles in the databases. Results: After applying the eligibility criteria, 27 articles were selected for reading, being that one article was excluded by presenting irrelevant result and another was excluded by duplication. From the 25 articles, one was published in 2015, three in 2014, one in 2013, three in 2012, five in 2011, two in 2010, three in 2009, four in 2008, two in 2004 and one in 1996. In relation to the studies, nine were clinical trials, 10 systematic reviews, five cross-sectional studies and one essay. Conclusion: The most frequently methods applied are the VAS and the McGill's Questionnaire, considering the multidimensional pain assessment. The most commonly used questionnaire to evaluate QoL is the SF-36. There is great difficulty to classify methods for assessing pain and QoL (qualitative or quantitative methods), since many authors report the same method when addressing the two interfaces.

Indexing terms: Methods. Qualitative analysis. Quantitative analysis. Quality of life. Pain.

\section{RESUMO}

Objetivo: A necessidade em quantificar a dor e qualidade de vida (QV) é essencial para o profissional quanto a sua conduta terapêutica. O objetivo desta revisão é identificar os métodos de análise qualitativa e quantitativa da dor e QV validadas no Brasil.

1 Universidade do Vale do Paraíba, Instituto de Pesquisa e Desenvolvimento, Curso de Odontologia da Faculdade de Ciências da Saúde. Av. Shishima Hifumi, 2911, Urbanova, 12244-000, São José dos Campos, SP, Brasil. Correspondência para / Correspondence to: LJ MASULO. E-mail: <l.masulo@hotmail.com>.

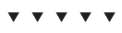

Masulo LJ, Martins MLS, Costa DR, Nicolau RA. I. Methods for qualitative and quantitative analysis of pain and quality of life validated in Brazil - systematic review. RGO, Rev Gaúch Odontol. 2019;67: e20190022. http://dx.doi.org/10.1590/1981-86372019000223435 
Métodos: Revisão realizada através das bases de dados LILACS, SciELO, MedLine e Google Acadêmico com os descritores: "métodos", "análise qualitativa", "análise quantitativa", "dor" e "qualidade de vida". Critérios de inclusão: Artigos publicados português e inglês no período compreendido entre 1996 a 2015. Critérios de exclusão: textos incompletos, artigos que não abordam a temática do estudo e repetição de um mesmo artigo nas bases de dados. Resultados: Após aplicação dos critérios de elegibilidade foram selecionados 27 artigos para leitura, dos quais foi excluído um artigo por não apresentar resultado relevante e outro por repetição. Dos 25 artigos, um foi publicado em 2015, três em 2014, um em 2013, três em 2012, cinco em 2011, dois em 2010, três em 2009, quatro em 2008, dois em 2004 e um em 1996. Em relação aos estudos, nove são ensaios clínicos, 10 revisões sistemáticas cinco estudos transversais e uma dissertação. Conclusão: Os métodos mais utilizados são EVA, em caso de análise multidimensional da dor o mais citado é Questionário de McGill. O questionário para avaliação de QV mais utilizado é o SF-36. Existe uma grande dificuldade em classificar os métodos de avaliação da dor e QV (qualitativo ou quantitativo), uma vez que muitos autores citam o mesmo método abordando as duas interfaces.

Termos de indexação: Métodos. Análise qualitativa. Análise quantitativa. Dor. Qualidade de vida.

\section{INTRODUCTION}

Pain, from the Latin dolore, is an unpleasant sensory and emotional experience [1]. The sensation of pain is essential for survival and the first indicator of any tissue damage. Any stimulus, which results in damage or injury, leads to a sensation of pain, such as heat, cold, pressure, electric current, chemical irritants and even sudden movements. Pain can also be defined as a subjective experience associated, or not, to real or potential tissue damage [2].

The perception of pain is characterized as a multidimensional experience, diversifying in quality and sensorial intensity, being affected by affective-motivational variables [2-5].

The American Agency for Health Care Research and Quality and the American Society of Pain describe pain as the fifth vital sign. The American Academy of Emergency Medicine recognizes the importance of recording and measuring the perception of both acute and chronic pain [6]. Subjective concepts and facts, such as pain, are difficult to accurately measure or quantify through instruments and processes free of systematic errors. Pain perception differs from subjects because it is an internal, complex and personal experience, influenced by cultural, behavioral, situational, emotional and additional psychological and external variables [7]. However, pain measurement, both in the clinical and the scientific settings, is extremely important. Measuring instruments/pain analysis make it possible to assess its origin and sources of exacerbation or attenuation, often considering multidimensional aspects (Example: clinical correlation vs personality of the subject).

Several instruments have been used to quantify pain, among the ones that are the most used in hospitals and clinical settings are the one-dimensional scales. Onedimensional instruments can be used for quick responses in quantifying pain in relation to its intensity [1]. There are multidimensional instruments that aim at covering, besides the intensity factor, reporting the sensorial, affective and emotional aspects. Some of these instruments also present physiological, behavioral and contextual indicators, as well as information provided by the patient [5].

Pain assessment is of great importance to direct a treatment, however, the evaluation of the quality of life (QoL) becomes necessary for the clinical setting. Considering the etymology of the word quality, that derives from the Latin quails, it means the way of being of something, both considered in itself and related to other groups, thus being able to take both positive and negative characteristics [8].

QoL is a concept that is often mistaken by lifestyle, living conditions and life situations. Despite having several studies reporting on the subject, its definition is not yet a consensus. Its evaluation considers qualitative instruments that use biographies, associated with quantitative evaluations, aiming at building and validating multidimensional analyzes [8].

In health care, the interest for QoL is relatively new and results, in part, come from the new paradigms that have influenced the policies and practices in the area in the last decades. Within the scope of collective health and public policies, it is also possible to identify a growing interest for QoL. Thus, information on this subject has been included as an indicator to evaluate the efficacy, efficiency and impact of some treatments on groups and patients, comparing procedures to control health problems [9].

Evaluating the QoL indicators is nothing more than inferring on the impact of the disease in the physical and mental aspects of the patients, through questionnaires and instruments, representing the best attempt to cover the entire extent of the disease [10]. 
Therefore, defining the methodological aspects to assess pain and QoL becomes necessary in health care, both at the clinical and scientific levels. Thus, this current study presents a systematic review to identify the current methods of qualitative and quantitative analysis of pain and quality of life validated in Brazil.

\section{METHODS}

For the preparation of the present research study, the following methodological procedures were followed: definition of the objective, establishment of the criteria to perform the inclusion and exclusion analyzes; classification of the studies; evaluation of the studies included in the research and presentation of the results. The selection of the material was carried out from July to August 2016. For the selection of articles, four electronic databases were used: LILACS (Latin American and Caribbean Literature in Social and Health Sciences), SciELO (Scientific Electronic Library Online), MedLine (Medical Literature Analysis and Retrieve System Online) and Google Scholar. The descriptors were selected by the DeCS (Health Sciences Descriptors), being them methods, qualitative analysis, quantitative analysis, pain and quality of life. The inclusion criteria contained articles that were available in full, published in Portuguese or in English, from 1996 to 2015, and aiming at showing the progress of the methodological practices over the years. The exclusion criteria were for duplicate articles found in different databases, in which only one was chosen to be part of the study; and incomplete articles that did not directly address the topic of study or did not achieve relevant research results.

\section{RESULTS}

From the descriptors analyzed, 27 publications were obtained. After applying the eligibility criteria, 27 articles were selected for reading, in which one article was excluded by presenting irrelevant result and another was excluded by duplication. Thus, 25 studies were included in the review (23 national papers and 2 international papers published in English). From the 25 articles, one was published in 2015, three in 2014, one in 2013, three in 2012, five in 2011, two in 2010, three in 2009, four in 2008, two in 2004 and one in 1996. In relation to the drawings, nine were clinical trials, 10 systematic reviews, five cross-sectional studies and one essay.
Table 1 presents the characteristics of the studies and the methods for pain assessment and QoL used as years passed by, as well as their real meaning to the treatment. All the analyzed studies have reported a method to assess pain and QoL. Although there is a wide variety of applicable methods, it is difficult to classify them quantitative or qualitatively. The articles gathered for this study were classified according to a meta-analysis table (table 1), being classified by "Author", "Country of Origin/ Language", "Study Design", "Pain Analysis", "Quality of Life Analysis", "Type of Analysis" and "Results".

\section{DISCUSSION}

Studies reporting on pain and quality of life are analyzed qualitative and quantitatively. The two research strategies, in terms of applicability, are referred as qualitative and quantitative approaches, using a very broad classification. These methods are differentiated by the way they approach the problem and the systematic applied. Quantitative research uses quantification to gather and analyze information, applying statistical techniques, aiming at avoiding analysis and interpretation interferences, providing a greater safety margin [26]. One-dimensional scales are limited to a single pain aspect, just the intensity of pain felt at a given moment, disregarding other important aspects of pain such as location, sensory and affective characteristics, and the use of medication among others [19].

The visual analogue scale (VAS) is a onedimensional measurement instrument that assess pain intensity, consisting of a not-numbered straight line, indicating, at one end, no pain and, and at the other end, the worst possible pain felt. The patient is asked to evaluate and mark, on the line, the pain felt at the moment $[4,26]$. According to Buss and Silva [10], more cognitively impaired patients had difficulty in understanding the VAS, which can be attributed to the greater difficulty of this group in defining a single global health assessment score based on their perception. According to Nascimento and Silva [4], the VAS can be very useful to assess pain as it is a simple instrument. However, corroborating with Buss and Silva [10], the use of VAS may be inappropriate for patients with low levels of education and with cognitive and visual impairment. VAS often consists of a $10-\mathrm{cm}$ straight line, being zero no pain and ten the maximum pain felt (figure 2). 
Table 1. Articles included in the review organized by chronological order of publication: authors/year, country of origin/language, study, pain analysis, QOL analysis and results.

\begin{tabular}{|c|c|c|c|c|c|c|}
\hline AUTHOR & $\begin{array}{c}\text { COUNTRY OF } \\
\text { ORIGIN/LANGUAGE }\end{array}$ & STUDY & PAIN & QoL & ANALYSIS & RESULTS \\
\hline Panhoca et al. [11] & Brazil/English & $\mathrm{CT}$ & DP & NC & $\mathrm{DP}=\mathrm{Qtt}$ & $\begin{array}{l}\text { LED devices help in the } \downarrow \text { of TMD } \\
\text { pain. }\end{array}$ \\
\hline Ahrari et al. [12] & Ira/English & $\mathrm{CT}$ & VAS & NC & $\mathrm{VAS}=\mathrm{Qtt}$ & mouth opening and pain. \\
\hline Demirkol et al. [13] & Turkey/English & $\mathrm{CT}$ & VAS & NC & $\mathrm{VAS}=\mathrm{Qtt}$ & LITL effective against MPs \\
\hline Nascimento et al. [4] & Brazil / Portuguese & RA & $\begin{array}{l}\text { VNS, } \\
\text { VAS,FS }\end{array}$ & NC & $\begin{array}{l}\mathrm{VNS}=\mathrm{Qtt} \\
\mathrm{VAS}=\mathrm{Qtt} \\
\mathrm{FS}=\mathrm{Qtt}\end{array}$ & $\begin{array}{l}\text { There are several tools for pain } \\
\text { assessment, however, it will depend } \\
\text { on the physical, mental and social } \\
\text { condition of the patient. }\end{array}$ \\
\hline Catão et al. [14] & Brazil/Portuguese & CT & VAS & NC & $\mathrm{VAS}=\mathrm{Qtt}$ & mouth opening and pain. \\
\hline Andrade et al. [15] & Brazil/Portuguese & $C T$ & QDI & $\begin{array}{l}\text { UW-QOL, } \\
\text { QOL H\&N C-35, }\end{array}$ & $\begin{array}{c}\text { QDI=Qlt } \\
\text { UW-QOL= QIt } \\
\text { QLQ H\&N } \\
\text { C-35=Qlt }\end{array}$ & $\begin{array}{l}\text { QoL questionnaires from the } \\
\text { University of Washington validated } \\
\text { for Brazil and QoL questionnaire for } \\
\text { cancer patients. }\end{array}$ \\
\hline Ferro et al. [16] & Brazil/Portuguese & $\mathrm{E}$ & NC & $\begin{array}{l}\text { WHOQOL-100, } \\
\text { WHOQOL-Bref }\end{array}$ & $\begin{array}{l}\text { WHOQOL-100=Qlt } \\
\text { WHOQOL-Bref=Qlt }\end{array}$ & $\begin{array}{l}\text { The different types of QoL } \\
\text { questionnaires at Work. }\end{array}$ \\
\hline Pereira et al. [17] & Brazil/Portuguese & RA & NC & $\begin{array}{c}\text { HDI, } \\
\text { SF-36, } \\
\text { WHOQOL, } \\
\text { WHOQOL-100, } \\
\text { WHOQOL-Bref }\end{array}$ & $\begin{array}{c}\mathrm{HDI}=\mathrm{Q} \mid \mathrm{t} \\
\mathrm{SF}-36=\mathrm{Q} / \mathrm{t} \\
\text { WHOQOL=QIt } \\
\text { WHOQOL-100=QIt } \\
\text { WHOQOL-Bref=Qlt }\end{array}$ & $\begin{array}{l}\text { There are several questionnaires to } \\
\text { measure QoL, but they differ when } \\
\text { the question is related to different } \\
\text { cultures. }\end{array}$ \\
\hline Marques et al. [18] & Brazil/Portuguese & RA & $\begin{array}{l}\text { VNS, } \\
\text { VAS, } \\
\text { McGill }\end{array}$ & $\begin{array}{l}\text { HT, } \\
\text { BT }\end{array}$ & $\begin{array}{c}V N S=Q t t \\
V A S=Q t t \\
\text { McGill=QIt } \\
H T=Q t t \\
\text { BT=Qtt }\end{array}$ & Contextualization on pain. \\
\hline Martinez et al. [19] & Brazil/Portuguese & CT & $\begin{array}{l}\text { BPI, } \\
\text { EVA, } \\
\text { McGill }\end{array}$ & NC & $\begin{array}{c}\text { BPI=Qtt } \\
V A S=Q t t \\
\text { McGill=QIt }\end{array}$ & $\begin{array}{l}\text { Multidimensional instruments for } \\
\text { pain assessment have limitations in } \\
\text { different clinical settings. }\end{array}$ \\
\hline $\begin{array}{l}\text { Mascarenhas et al. } \\
\text { [20] }\end{array}$ & Brazil/Portuguese & $\mathrm{CT}$ & $\begin{array}{l}\text { VAS, } \\
\text { McGill, } \\
\text { RMB }\end{array}$ & NC & $\begin{array}{l}\text { VAS=Qtt } \\
\text { McGill=QIt } \\
\text { RMB }=\text { QIt }\end{array}$ & $\begin{array}{l}\text { Pain chart and the functional } \\
\text { modifications of subjects presenting } \\
\text { chronic low back pain need a } \\
\text { thorough evaluation. }\end{array}$ \\
\hline $\begin{array}{l}\text { Nascimento et al. } \\
\text { [4] }\end{array}$ & Brazil/Portuguese & CT & VNS, & NC & $\begin{array}{l}\mathrm{VNS}=\mathrm{Qtt} \\
\mathrm{QDI}=\mathrm{Q} \mid \mathrm{t}\end{array}$ & $\begin{array}{l}\text { Nurse's role in supervising and } \\
\text { training. }\end{array}$ \\
\hline Silva et al. [2] & Brazil/Portuguese & CT & $\begin{array}{l}\text { MSA, } \\
\text { ASDT, } \\
\text { PS, BI }\end{array}$ & NC & $\begin{array}{c}\mathrm{MSA}=\mathrm{Qtt} \\
\mathrm{ASDT}=\mathrm{Q} \mid \mathrm{t} \\
\mathrm{PS}=\mathrm{Qtt} \\
\mathrm{Bl}=\mathrm{Q} \mathrm{lt}\end{array}$ & $\begin{array}{l}\text { Several possible ways to measure } \\
\text { pain. }\end{array}$ \\
\hline Morete et al. [21] & Brazil/Portuguese & CT & $\begin{array}{l}\text { VNS, } \\
\text { VAS, } \\
\text { FS, } \\
\text { BPI }\end{array}$ & NC & $\begin{array}{c}V N S=Q t t \\
V A S=Q t t \\
F S=Q t t \\
B P I=Q t t\end{array}$ & $\begin{array}{l}\text { Survey of various means to assess } \\
\text { pain. }\end{array}$ \\
\hline
\end{tabular}


Table 1. Articles included in the review organized by chronological order of publication: authors/year, country of origin/language, study, pain analysis, QOL analysis and results.

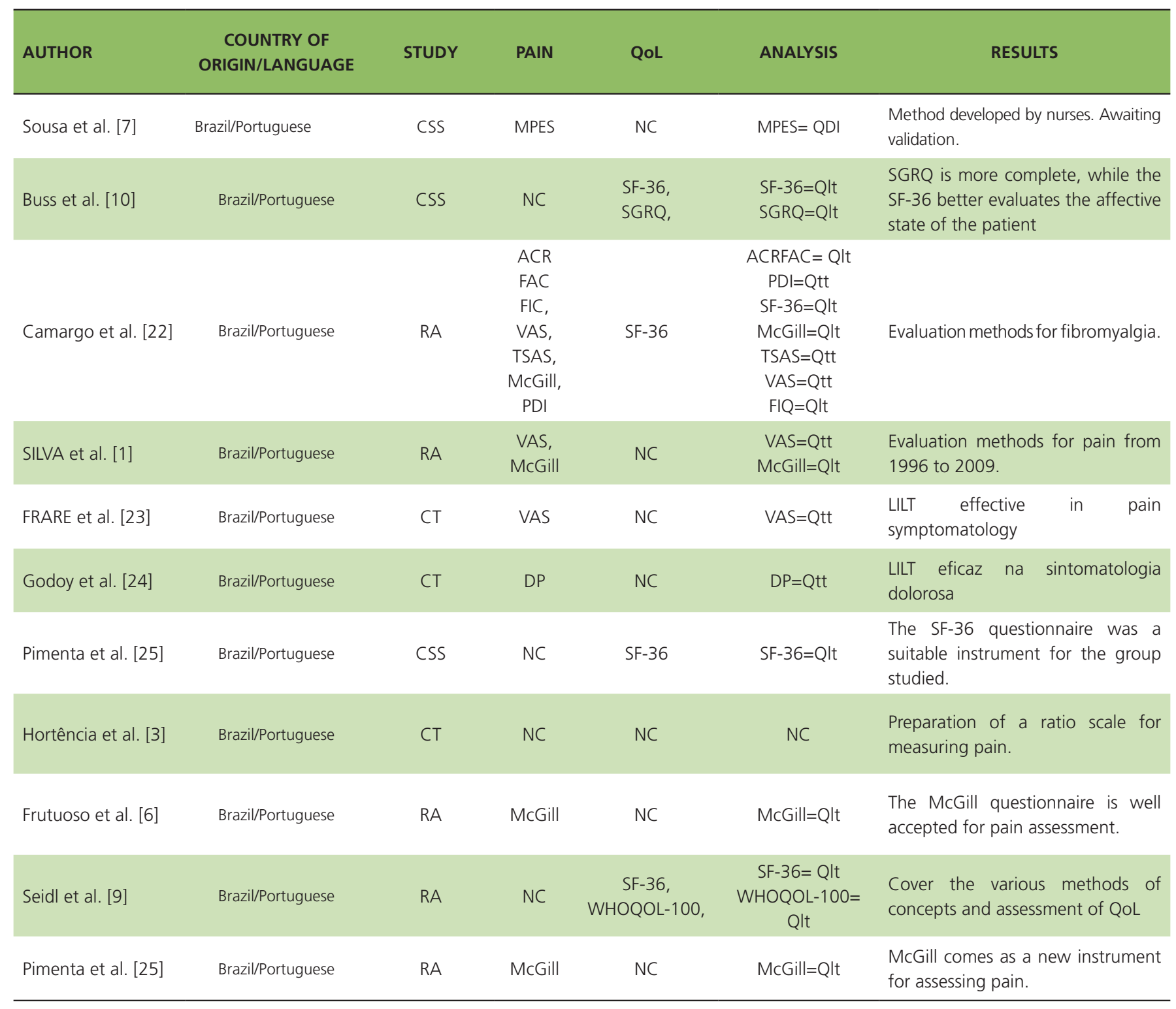

The visual numerical scale (VNS) is another type of pain scale which is graded from zero to ten, being zero no pain and ten the worst possible pain felt (figure 3). The VNS is a one-dimensional instrument and differs from the VAS by being graded. Digital palpation (DP) ranges from zero to three: zero (no pain), one (mild pain), two (moderate pain) and three (severe pain), being the result of pain induced by the palpation with the fingers of the professional [11].

Face Scale (FS) is a scale of facial expression numbered from zero to ten, in which the patient associates numerically the pain to the face drawn (figure 4). According to Morete et al. [21], this scale allows the objective assessment of pain. According to Nascimento and Silva [6] and Buss and Silva [10], FS can overcome VAS in efficiency in patients with lower cognition levels. Psychophysical scale (SS) is a one-dimensional paired scale that quantifies each component separately. If differential estimates are obtained, a distinction is confirmed for the affective sensory dimensions [2]. These instruments assess pain by numerical scale, ranging from zero to ten or, from zero to three, generating a great deal of variation from person to person, since pain is subjective and characterized by an unpleasant 


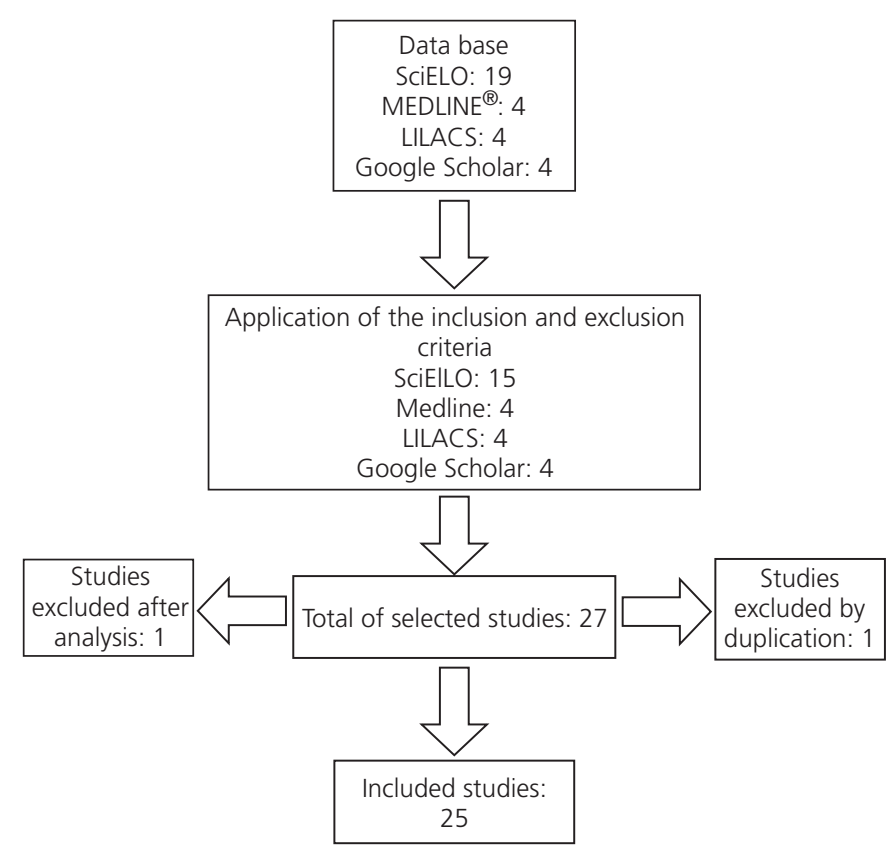

Figure 1. Flowchart for the selection of the studies used in the literature review on qualitative and quantitative methods for pain and quality of life.

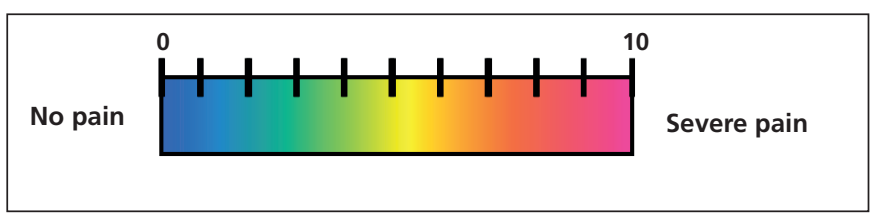

Figure 2. Visual Analogue Scale - VAS.

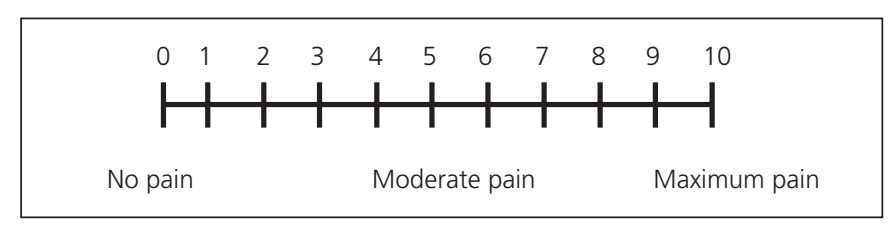

Figure 3. Visual Numerical Scale - VNS.

sensory and emotional experience, associated, or not, to tissue damage. Pain does not depend only on the intensity of the stimulus, as analyzed one-dimensionally. Pain is influenced by psychosocial and neurosensitive factors, suffering modulation in the central nervous system, as well as interaction between the nociceptive stimuli and the modulating factors, resulting in sensorineural experience. The quality and amount of pain varies according to the person's perception (culture, anxiety level, abstraction ability of the pain felt and controlled) of the pain-generating situation, as well as the previous experience that triggers the pain [18].

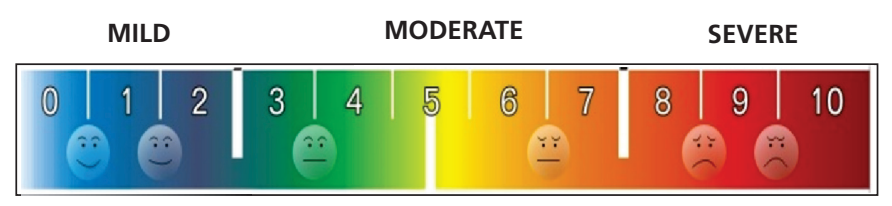

Figure 4. Face Scale - FS.

The Brief Pain Inventory (BPI) (figure 5) is a quantitative analysis that, using a scale from zero to ten, quantifies pain intensity and its interference in walking, daily and social activities, work, humor and sleep. Pain assessment by the patient is presented in the questionnaire as the most severe, the least intense and the average pain felt in the last twenty-four hours. This is also considered a multidimensional instrument. In the study carried out by Martinez et al. [19], this questionnaire was compared to other evaluation methods and was chosen by patients as the best one to assess pain. It also evaluates the treatment and the relief brought by it, as well as the impact on the patient's daily life, besides containing relevant information for evaluation such as age and sex. The qualitative methods for pain analysis differ from the quantitative ones, as they do not use statistical instruments to analyze a problem, not intending to measure or number categories. Qualitative data includes information not expressed in words such as paintings, photographs, drawings, films, videos and even soundtracks, thus, providing several interpretations of an inductive analysis by the researcher [26]. Among the methods applied for qualitative assessment of pain, there is the McGill Questionnaire. The McGill pain questionnaire consists of seventy-eight descriptors (words that qualify pain), organized into four categories (sensory, affective, evaluative and mixed) and twenty subcategories. One word from each subcategory is chosen, however, there is also the option of not choosing a word. The analysis is done by categories, by means of the sum of the values associated to the chosen words. This is a multidimensional instrument, containing a body diagram for better localization and assessment of pain as to its frequency and extension [8,19]. According to Martinez et al. [19], patients who have filled out this questionnaire have evaluated it as extensive and time-consuming, especially for being filled 
Date:

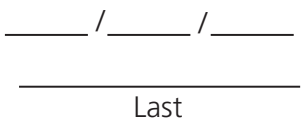

Last
Time:

Name:
First $\overline{\text { Middle intial }}$
7) What treatments or medications are you receiving for your pain?
1) Throughout our lives, most of us have had pain from time to time (such as minor headsaches, sprains, and toothaches) Have you had pain other than these everyday kinds of pain today?

\section{Yes 2. No}

2) On the diagram, shado in the areas where you feet pain, Put an $\mathrm{X}$ on the area that hurts the most.
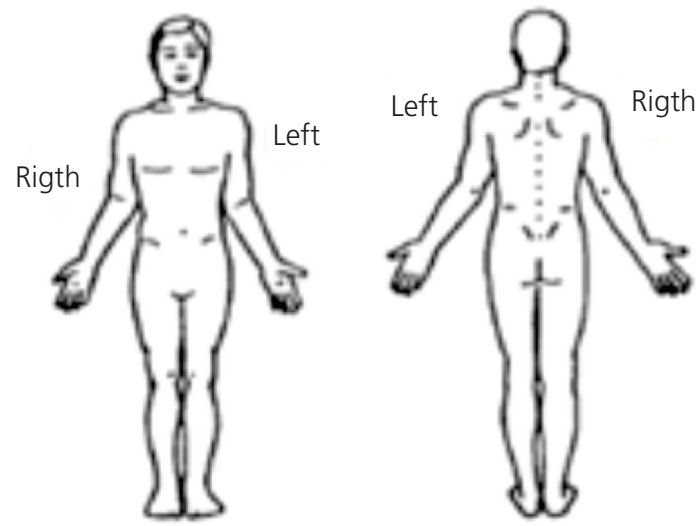

3) Plesase rate your by circling the one number that best describes your pain at its worst in the past 24 hours.

$\begin{array}{lllllllll}0 & 1 & 2 & 3 & 4 & 5 & 6 & 7 & \begin{array}{c}8 \\ \text { Pain as bad as } \\ \text { No }\end{array} \\ \text { pain } & & & & & & \\ \text { you can imagine }\end{array}$

4) Please rate your pain by circling the one number that best describes your pain at its least in the past 24 hours.

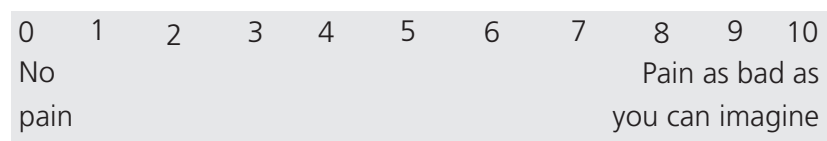

5) Please rate your pain by circling the one number that best describes your pain on average

$\begin{array}{llllllllll}0 & 1 & 2 & 3 & 4 & 5 & 6 & 7 & \begin{array}{c}8 \\ \text { Pain as bad as } \\ \text { No }\end{array} \\ \text { pain } & & & & & & \\ \text { you can imagine }\end{array}$

6) Please rate your pain by circling the one number that tells how much pain you have right now.

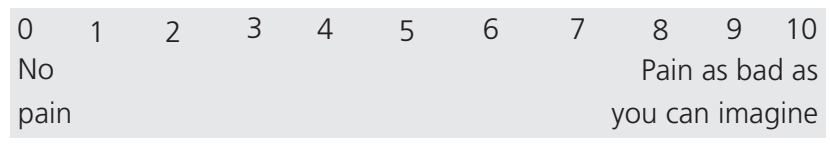

8) In the past 24 hours, how much relief have pain treatments or medications provided? Please circle the one percentage that most shows how much relief you have received.

$\begin{array}{llllllllll}0 \% & 10 & 20 & 30 & 40 & 50 & 60 & 70 & 80 & \begin{array}{c}90 \\ \text { Complete } \\ \text { No } \\ \text { relief }\end{array}\end{array}$

9) Circle the one number that describes how, during the past 24 hours, pain has interfered with your:

A. General activity

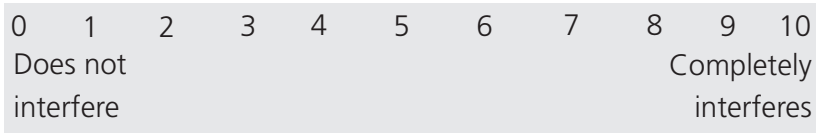

B. Mood

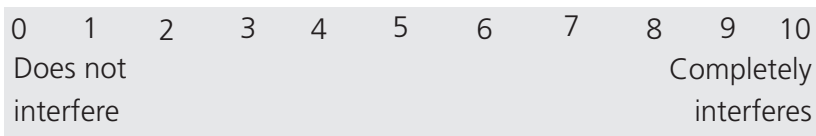

C. Walking ability

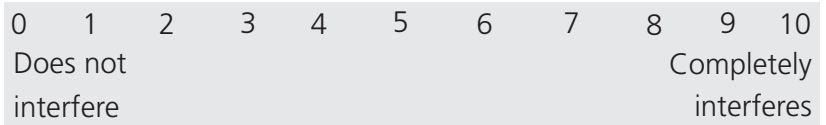

D. Normal work (includes both work outside the home and housework)

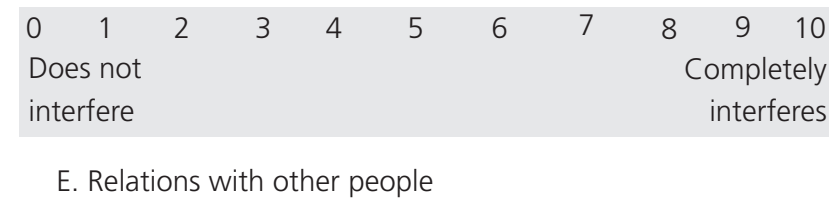

\begin{tabular}{|c|c|c|c|c|c|c|c|}
\hline $\begin{array}{l}0 \quad 1 \\
\text { Does not } \\
\text { interfere }\end{array}$ & 2 & 3 & 4 & 5 & 6 & 7 & $\begin{array}{r}8 \quad 9 \quad 10 \\
\text { Completely } \\
\text { interferes }\end{array}$ \\
\hline F. Sleep & & & & & & & \\
\hline $\begin{array}{l}0 \quad 1 \\
\text { Does not } \\
\text { interfere }\end{array}$ & 2 & 3 & 4 & 5 & 6 & 7 & $\begin{array}{r}8910 \\
\text { Completely } \\
\text { interferes }\end{array}$ \\
\hline
\end{tabular}

G. Enjoyment of life

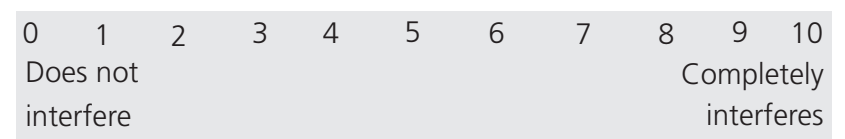

Figure 5. Brief Pain Inventory - BPI. 
out in the emergency room area. In contrast, Pimenta and Teixeira [25] consider the McGill pain questionnaire the best instrument, being the most used to characterize and differentiate the affective, sensitive and evaluative components of pain. It is considered a universal instrument capable of standardizing pain language. The Roland-Morris Brazil questionnaire, specific for measuring functional disability of patients, is composed by twenty-four questions related to the activities of the daily life, pain and function. For each question, one point is given. The score is the sum of the values, in which a minimum score of zero and a maximum score of twenty-four points can be achieved. This questionnaire has as cutoff point score fourteen, that is, patients evaluated with a score equal to or greater than fourteen are classified as functionally disabled [20].

Multivariate statistics (MS) has the purpose of verifying if, in fact, the pain descriptors fit along the dimensions described as sensory and affective. The methodology involves factor analysis (FA) and, to a lesser extent, multidimensional scaling (MDS) and cluster analysis. Common to all these procedures, there is the simultaneous analysis for variables without designating them as independent or dependent, to find out the latent structure of these variables. These procedures show indications that clearly allow the separation of the sensory and the affective pain components [20].

In contrast to the multivariate statistical analysis, the Signal Detection Theory (SDT) has often allowed experimental demonstration of the pain components. The identification of these components has also been questioned. Interpretation is open to challenges. The response criterion represents the readiness to record pain, and this ratio contains a lot of psychological variables such as attitude, reward, demanding characteristics and personality, being emotion one of the factors. Medical and psychological interventions involving the use of sedatives also identify an affective component distinct from the sensory properties of pain. The ASDT makes a considerable distinction between the sensory and the psychological elements of pain [20].

In more advanced studies, cerebral imaging techniques, such as the positron emission tomography (PET) and the functional magnetic resonance imaging (MRI), are used to investigate the neural basis of the complex and emotional sensory pain experience. By analyzing the perception, along with the neural activity in conscious human beings, studies have shown how the brain processes the complex sensation of pain. A combination of multiple perceptual measurement indicators with brain imaging allows researchers to check the neural determination of the several aspects of the pain experience [20]. Pain assessment requires a quantitative approach, employing appropriate scales to the patient profile, and a qualitative approach, emphasizing descriptive aspects of pain and its impact on the functions and activities of the daily life [21].

QoL is a concept that is increasingly applied in the evaluation of the health conditions of a person, as well as in the impact of therapeutic applications associated with different diseases [17]. Quality of life information can be obtained systematically by semi-structured interviews and qualitative evaluations; however, questionnaires have been consolidated as the most used resource due to the operational easiness related to cost and the analysis of results [15]. QoL questionnaires aim at seeking a better understanding of the overall condition of a person evaluating different aspects. One of the questionnaires applied was the University of Washington Quality of Life Questionnaire (UW-QoL) (version 4), Portuguese version validated for use in Brazil, which evaluates patients with head and neck cancer. The questionnaire contains twelve questions with multiple choices, addressing areas on quality of life as pain, appearance, activity, recreation, swallowing, chewing, speech, shoulders, taste, saliva, mood and anxiety. The questionnaire also contains additional open and closed questions, so that patients can express their general state on quality of life, considering not only the functional aspects but, also, family and social and spiritual contexts in which are inserted. The scores for the multiple-choice questions were previously established by the authors. The score alternatives range from zero (minimum) to one hundred (maximum), observing the scalar organization of the responses that are indicative of higher and lower impact. All the questions follow the same score, with higher scores representing desirable conditions, while lower values correspond detrimental impacts on the quality of life, with no issues with inverted scores. The scale, thus, allows to evaluate each area of the quality of life by means of specific scores [15].

The EORTC QLQ E \& N C-35 have a total of sixtyfive questions, which were developed by the European Organization for Cancer Research and Treatment, which has shown that both provide satisfactory results for such an evaluation, being the EORTC QLQ E \& N C-35 also applied globally. The SF-36 quality of life questionnaire is generic, 
with the purpose of evaluating the quality of life of patients with any type of condition. Such questionnaire comprises thirty-six questions and is subdivided into eight areas as functional ability, body pain, vitality, general health, social function, physical and emotional function and mental health. These areas can be put together with two major groups being them the physical component summary and the mental component summary. The value ranges from zero to one hundred and higher numbers represent better health-related quality of life $[15,22]$.

The Saint George Hospital Respiratory Questionnaire (SGRQ) is self-managing and consists of fifty items and is divided into three areas as symptoms (eight items), activity (sixteen items) and impact (twenty-six items). Each item has a secondary weight, and the lower values indicate a better health-related quality of life [10]. This is a more comprehensive questionnaire, but comparatively, the SF36 questionnaire emphasizes the patient's affective status. The most complete questionnaire is the WHOQOL-100, a quality-of-life assessment instrument composed of 100 items distributed in six areas and twenty-four facets. With the need to have shorter questionnaires requiring less time to be filled out, but maintaining the main characteristics, the WHO has developed a shorter version of the WHOQOL-100 questionnaire, that is, the WHOQOL-bref, which consists of twenty-six questions, being two general questions about quality of life and the other twenty-four facets that make up the original instrument. Thus, each facet is evaluated only by one question, unlike the WHOQOL-100 which, in each of the twenty-four facets, is evaluated from four questions. The short version of the WHOQOL-100 has proven to be a suitable option for situations in which the long version is difficult to be applied [16]. In contrast to additional QoL questionnaires, the WHOQOL-100 can be exhaustive and inefficient, considering that it is extensive and complex, but more reliable than the other questionnaires. Considering the questionnaires SF-36 and SGRQ, although they are not mentioned much, they are well evaluated as they assess the affective state of the patient.

\section{CONCLUSION}

It was verified that, among the instruments analyzed, the tools most frequently used are the pain assessment one-dimensional scales (VAS and VNS). However, in case of a multidimensional method, the McGill
Questionnaire is the preferred one. During the study progress, it was verified difficulty to describe the methods for assessing pain, either qualitative or quantitatively, since many authors mention the same method when approaching both sides.

There are several questionnaires to assess quality of life, however, the most used one is the SF-36. Nonetheless, the WHOQOL-BREF is easy to apply and is the short version of the WHOQOL-100, which is adopted by the WHO. The WHOQOL-bref is considered a complete questionnaire and has several facets of analysis.

\section{Collaborators}

L MASULO, Dentist, researcher in the area of Low Level Laser Therapy an Pain in dentistry elaborated study design, data collection, analysus of data interpretation, as well as elaboration of the text of the manuscript for the important intellectual critique of its content and correction of the document with a dental point of view. MLS MARTINS, search of bibliographical data collected. Correction of the manuscript with a point of view expressed as Dentist and Master in Biomedical Engineering focused on health. DR COSTA, search of bibliographical data collected. Correction of the manuscript with point of view expressed as Dentist and Doctor of the area of Biomedical Engineering. RA NICOLAU, Master dentist and RhD in Biomedical Engineering and Medical Sciences, responsible for the research center and for the correction of the manuscript with points relating the topic addressed.

\section{REFERENCES}

1. Silva FC, Deliberato PCP. Análise das escalas de dor: revisão de literatura. Rev Bras Ciênc da Saúde. 2009;7(9):86-9. http:// dx.doi.org/10.13037/rbcs.vol7n19.337

2. Silva JA, Ribeiro-Filho NP. A dor como um problema psicofísico. Rev Dor. 2011;12(2):138-51. http://dx.doi.org/10.1590/S18 06-00132011000200011

3. Hortense P, Zambrano E, Sousa FAEF. Validação da escala de razão dos diferentes tipos de dor. Rev Latino-Am Enfermagem. 2008;16(4):720-6. http://dx.doi.org/10.1590/S0104-1 1692008000400011

4. Nascimento JCC, Silva LCS. Avaliação da dor em pacientes sob cuidados em Unidades de Terapia Intensiva: uma revisão de literatura. Rev Movimenta. 2014;7(2):1984-4298.

5. Sousa FAEF. Dor: o quinto sinal vital. Rev Latino-am Enfermagem. 2002;10(3):446-7. http://dx.doi.org/10.1590/S0104-1169 2002000300020

6. Nascimento LA, Kreling MCGD. Avaliação da dor como quinto sinal vital: opinião de profissionais de enfermagem. Acta Paul Enferm. 2011;24(1):50-4. http://dx.doi.org/10.1590/S0103-21 002011000100007 
7. Sousa FF, Pereira LV, Cardoso R, Hortense P. Escala Multidimensional de Avaliação de Dor (EMADOR). Rev Latino-Am Enfermagem. 2010;18(1):001-9. http://dx.doi.org/10.1590/S0 104-11692010000100002

8. Pimenta FAP, Simil FF, Tôrres HOG, Amaral CFS, Rezende CF, Coelho TO, et al. Avaliação da qualidade de vida de aposentados com a utilização do questionário SF-36. Rev Assoc Med Bras. 2008;54(1):55-60. http://dx.doi.org/10.15 90/S0102-311X2004000200027

9. Seidl EMF, Zannon CMLC. Qualidade de vida e saúde: aspectos conceituais e metodológicos. Cad Saúde Pública. 2004;20(2):580-8. http://dx.doi.org/10.1590/S0102-311X2004 000200027

10. Buss AS, Silva LMC. Estudo comparativo entre dois questionários de qualidade de vida em pacientes com DPOC*. J Bras Pneumol. 2009;35(4):318-24. http://dx.doi.org/10.1590/ S1806-37132009000400005

11. Panhoca VH, Lizarelli RFZ, Nunez SC, Pizzo RCA, Grecco C, Paolillo FR, et al. Comparative clinical study of light analgesic effect on temporomandibular disorder (TMD) using red and infrared led therapy. Lasers Med Sci. 2015;30:815-22. doi: 10.1007/s10103-013-1444-9

12. Ahrari F, Madani AS, Ghafouri ZS, Tunér J. The efficacy of low-level laser therapy for the treatment of myogenous temporomandibular joint disorder. Lasers Med Sci. 2014;29(2):551-7. doi: 10.1007/s10103-012-1253-6

13. Demirkol N, Sari F, Bulbul M, Demirkol M, Simsek I, Usumez A. Effectiveness of occlusal splints and low-level laser therapy on myofascial pain. Lasers Med Sci. 2015;30(3):1007-12. doi: 10.1007/s10103-014-1522-7

14. Catão MHCV, Oliveira PS, Costa RO, Carneiro VSM. Avaliação da eficácia do laser de baixa intensidade no tratamento das disfunções têmporo-mandibular: estudo clínico randomizado. Rev CEFAC. 2013;15(6):1601-8. http://dx.doi.org/10.1590/S15 16-18462013005000052

15. Andrade FP, Biazevic MGH, Toporcov TN, Togni J, Carvalho $\mathrm{MB}$, Antunes JLF. Validade discriminante do questionário de qualidade de vida da Universidade de Washington no contexto brasileiro. Rev Bras Epidemiol. 2012;15(4):781-9. http://dx.doi.org/10.1590/\$1415-790X2012000400010

16. Ferro FF. Instrumentos para mediar a qualidade de vida no trabalho e a ESF: uma revisão de literatura [dissertação]. Brumadinho: Faculdade de Medicina da Universidade Federal de Minas Gerais; 2012
17. Pereira EF, Teixeira CS, Santos A. Qualidade de vida: abordagens, conceitos e avaliação. Rev Bras Educ Fís Esporte. 2012;26(2):241-50. http://dx.doi.org/10.1590/\$1807-5509 2012000200007

18. Marques JO. A dor e os seus aspectos multidimensionais. Ciênc Cult. 2011;63(2):28-32. http://dx.doi.org/10.21800/s0 009-67252011000200010

19. Martinez JE, Grassi DC, Marques LG. Análise da aplicabilidade de três instrumentos de avaliação de dor em distintas unidades de atendimento: ambulatório, enfermaria e urgência. Rev Bras Reumatol. 2011;51(4):299-308. http://dx.doi.org/10.1590/S0 482-50042011000400002

20. Mascarenhas CHM, Santos LS. Avaliação da dor e da capacidade funcional em indivíduos com lombalgia crônica. J Health Sci Inst. 2011;29(3):205-8.

21. Morete MC, Minson FP. Instrumentos para a avaliação da dor em pacientes oncológicos. Rev Dor. 2010;11(1):74-80.

22. Camargo RS, Moser ADL, Bastos LC. Abordagem dos métodos avaliativos em fibromialgia e dor crônica aplicada à tecnologia da informação: revisão da literatura em periódicos, entre 1998 e 2008. Rev Bras Reumatol. 2009;49(4):431-46. http://dx.doi.org/10.1590/S0482-50042009000400009

23. Frare JC, Nicolau RA. Análise clínica do efeito da fotobiomodulação laser (GaAs - 904 nm) sobre a disfunção temporomandibular. Rev Bras Fisioter. 2008;12(1):37-42. http://dx. doi.org/10.1590/S1413-35552008000100008

24. Godoy CHL, Silva PFC, Araujo DSA, Motta LJ, BiasottoGonzalez DA, Politti F, et al. Evaluation of effect of low-level laser therapy on adolescents with temporomandibular disorder: study protocol for a randomized controlled trial. Trials. 2013;14:229. doi: 10.1186/1745-6215-14-229

25. Pimenta CAM, Teixeira MJ. Questionário de dor mcgill: proposta de adaptação para a língua portuguesa. Rev Esc Enf USP. 1996;30(3):473-83. http://dx.doi.org/10.1590/S0080-62 341996000300009

26. Dalfovo MS, Lana RA, Silveira A. Métodos quantitativos e qualitativos: um resgate teórico. Rev Inter Cient Aplicada. 2008;2(4):1-13.
Received on: 24/5/2018 Final version resubmitted on: 8/6/2018 Approved on: 26/11/2018 